9

\title{
Effect of endurance training intensity (low, moderate and high) on the expression of skeletal muscle ATGL protein and serum levels of insulin and glucose in male diabetic rats
}

\author{
Dashti khavidaki M.H., PhD Candidate ${ }^{1}$, Faramarzi M., PhD ${ }^{2}$, Azamian Jazi A., PhD ${ }^{3}$, Banitalebi E., \\ $\mathbf{P h D}^{4}$ \\ 1. PhD student in Exercise Physiology, Shahrekord University, Shahrekord, Iran. \\ 2. Associate Professor in exercise physiology, Shahrekord University, Shahrekord, Iran (Corresponding Author),Tel:+98- \\ 38-32324401, md.faramarzi@ gmail.com \\ 3. Associate Professor in exercise physiology, Shahrekord University,Shahrekord, Iran. \\ 4. Assistant professor in exercise physiology, Shahrekord University, Iran.
}

\begin{abstract}
Background and Aim: The purpose of this study was to investigate the effect of endurance training intensity (low, moderate and high) on the expression of skeletal muscle ATGL protein and serum levels of insulin and glucose in male diabetic rats.

Material and Method: 40 streptozotocin induced diabetic male Wistar rats were randomly assigned to five groups of eight, including low (DL, moderate (DM) and high intensity (DH) endurance training diabetic groups, diabetic control group (D), and healthy control group (Con). Three sessions of endurance training with low intensity (DL) equivalent to 5-8 m / min, moderate intensity (DM) equivalent to $17-14 \mathrm{~m} / \mathrm{min}$ and high intensity (DH) equivalent to $25-22 \mathrm{~m} / \mathrm{min}$ were performed every week for eight weeks. The relative expression of ATGL protein was measured with western blot technique. Serum insulin and glucose levels were measured by ELISA method. To determine the difference between the groups we used one way ANOVA test.

Result: The results showed a significant difference in the expression of ATGL between the control and training groups (with low, moderate and high intensity) ( $\mathrm{p}=0.0002)$. This difference was significant between DH and D ( $\mathrm{p}=0.0049)$, DH and DL $(\mathrm{p}=0.0053)$ and also between $\mathrm{DH}$ and DM $(\mathrm{P}=0.0136)$ groups. Serum glucose levels were also significantly different between the DH group with the groups $\mathrm{D}(\mathrm{p}=0.002)$ and $\mathrm{DL}(\mathrm{p}=0.039)$, also, the DM group with groups $\mathrm{D}(\mathrm{p}=0.0018)$ and $\mathrm{DL}(\mathrm{p}=0.0165)$. There was a significant difference in the amount of insulin in the DH group compared to the groups DL $(p=0.011)$, $\mathrm{D}(\mathrm{p}=0.0002)$, and the DM group with $\mathrm{D}(\mathrm{p}=0.014)$.
\end{abstract}

Conclusion: Moderate and high intensity endurance training can to some extent compensate for diabetes-induced reduction in the expression of ATGL protein and cause reduction of serum insulin and glucose levels in diabetic rats. It seems higher intensity of endurance training can lead to greater increase in expression of ATGL in diabetic rats.

Keywords: Diabetes, ATGL, Endurance training intensity, Insulin, Glucose.

Received: Oct 17, 2017 Accepted: Jan 29, 2018 


\section{تأثير شدت تمرينات استقامتى (كمه متوسط و زياد) بر بيان ATGL عضله اسكلتى، سطوح

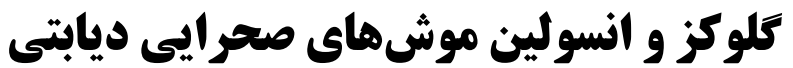

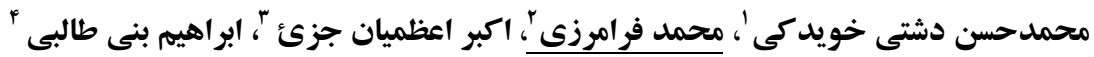

ا. دانشجوى دكترى فيزيولوزى ورزشى، گروه علوم ورزشى، دانشگاه شهر كرد ايران،

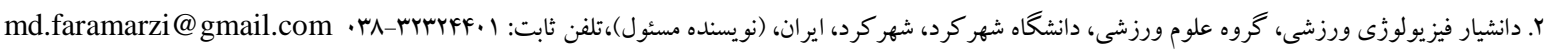

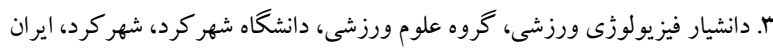

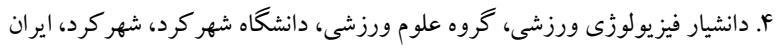

جكيل:

زمينه و هدف: هدف از اين مطالعه بررسى تأثير شدت هاى مختلف تمرينات استقامتى (كم، متوسط و زياد) بر بيان يروتئينى

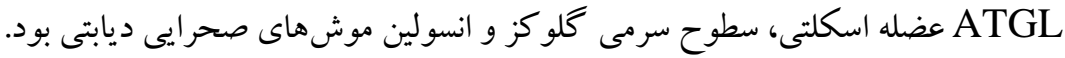

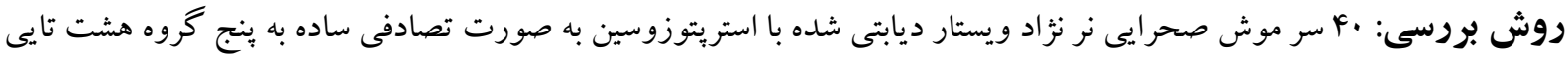

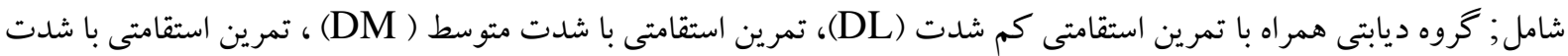

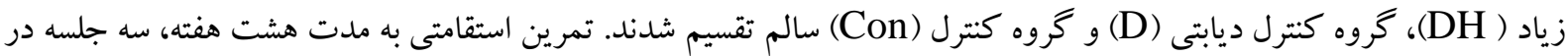

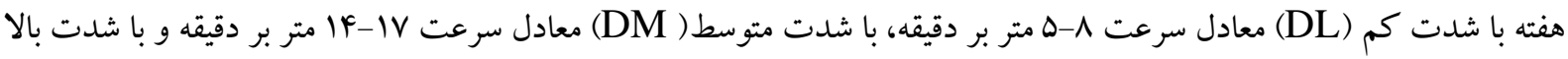
معادل سرعت هـ (DH ) تخصصى اندازهگيرى شد. از آزمون آمارى ANOVA جهت تعيين تفاوت بين گرووهها استفاده شد.

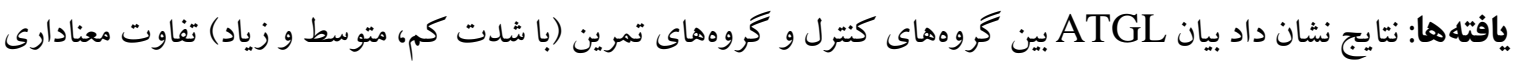

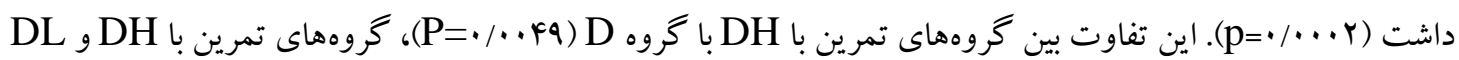

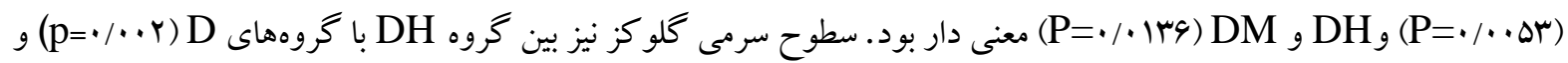

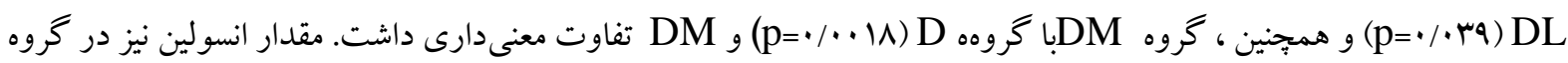

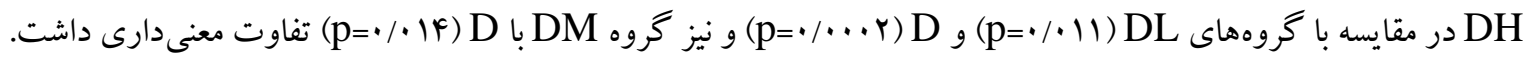
التيجه كيرى: تمرين استقامتى با شدت متوسط و زياد مى تواند تا حدودى كاهش ناشى از ديابت در بيان بروتئين ATGL جبران و باعث كاهش سطح سرمى انسولين و كلوكز در موشهاى ديابتى شود. به نظر مىرسد شدت بـ بالاتر تمرين استقامتى، افزايش بيشترى در بيان ATGL در موشهاى ديابتى ايجاد كند. وازكان كليدى: ديابت،ATGL، شدت تمرين استقامتى، انسولين، كلو كز

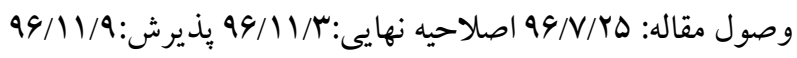


از طرفى، شدت و مدت تمرين بعنوان يكى از اصلىترين

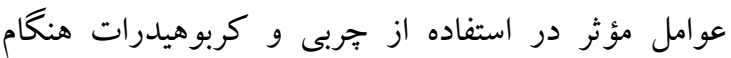

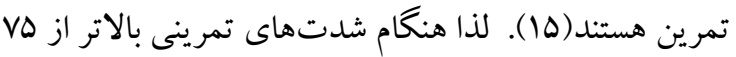
درصد VO جربى درون خود مى شود كه به عنوان يكك منبع انرزى مهم

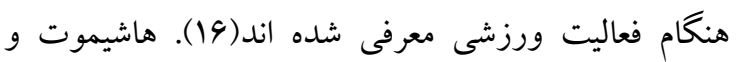
همكاران (T/Y.Y) درتحقيقى در مورد تاثير شش هفته تمرين هوازى با شدت متوسط بر روى موشهاى صحر ايى جاق نر

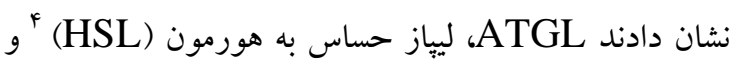

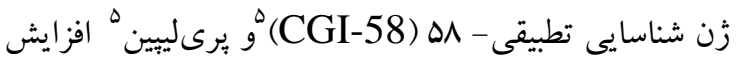

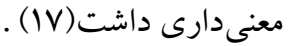
با توجه به اهميت، يافتن مكانيسمهاى درون سلولى تسهيل

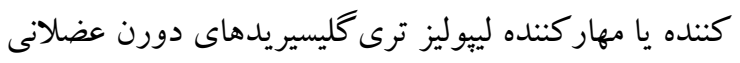
در كاهش يا افزايش فر آيندهاى التهابى ناشى از ديابت يا ساير اختلالات متابوليكى، بررسى عوامل تنظيم كننده ذخيره و آزاد شدن IMTG از جمله فعاليت ورزشى بسيار اهميت دارد. همجنين، درتحقيقات قبلى تا كنون تاثير شدتهاى مختلف تمرين استقامتى بر تغييرات ATGL بررسى نشده

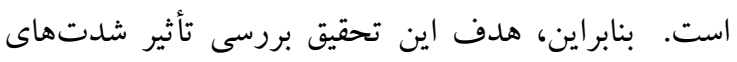
مختلف تمرينات استقامتى بر بيان بروتئين ATGL عضله

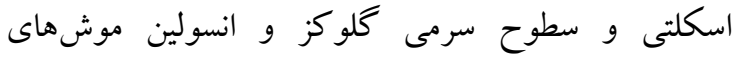
صحر ايى ديابتى بود.

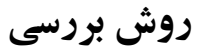

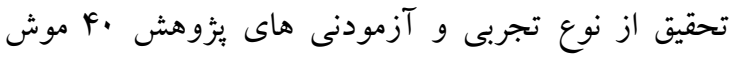

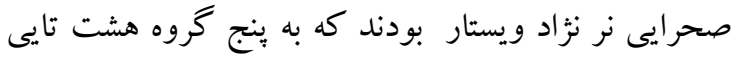
ديابت و تمرين استقامتى كم شدت(DL)، ديابت و تمرين

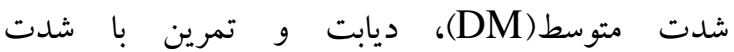
زياد(DH)، گروه كنترل ديابتى(D) و كنترل سالم(CON)

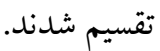

\footnotetext{
4- Hormone-sensitive lipases(HSL)
}

5- Comparative Gene Identification-58 (CGI-58)

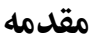

در افراد جاق، كمتحرك و ديابتى، غلظت بالاى ترى كليسريد درون عضلانى ' (IMTG) با مقاومت به انسولين همراه است(1). مقاومت به انسولين به عنوان يكك عامل خطرزاى مهم در بيمارى ديابت نوع دو و بيماريهاى قلبى عروقى شناخته شده است. بطور كلى، ميزان پيايين كردش IMTG به تنظيم منفى آبشار انسولين در بيماران

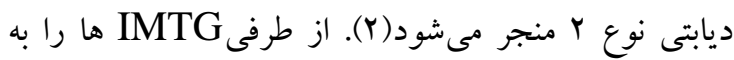

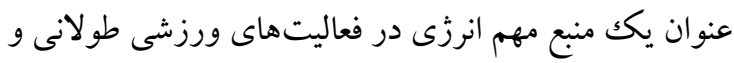

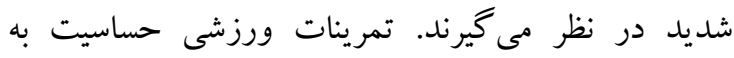

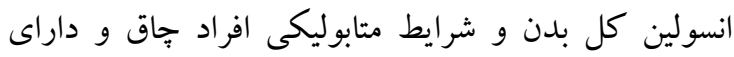

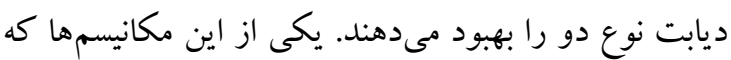
به وسيله آن تمرينات ورزشى مى توانند حساسيت به انسولين را بهبود دهد، افزايش بيان لييازها و كاهش مقدار خربى عضله اسكلتى است(r).

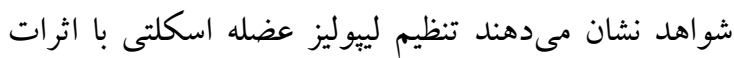
متقابل بروتئينهاى سطح قطره جربى تنظيم مى شود. به طور ويزّه، يكى از يروتين هاى قطره جربى كه به عنوان عامل

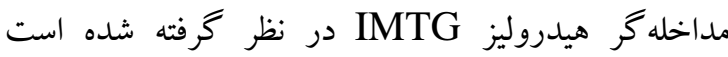

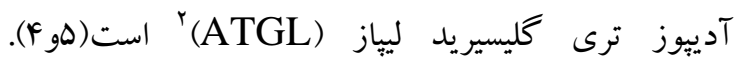
ATGL آنزيم محدود كننده سرعت هيدروليز ترى آسيل

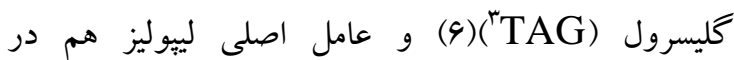
بافتهاى جربى(V-9) و هم در عضلههاى اسكلتى

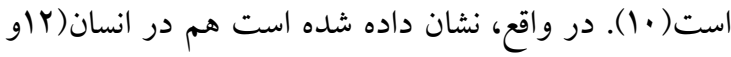
1) و هم در موش(r) (I) كمبود ATGL تجمع جشمخيرى در IMTGs عضلات قلبى و اسكلتى را ايجاد مى كند. از

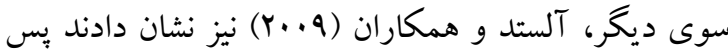
از ^ روز تمرينات استقامتى ATGL، عضلات اسكلتى دو

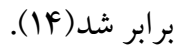

\footnotetext{
${ }^{1}$ Intramuscular Triglyceride

2 - Adipose triglyceride lipase (ATGL)

${ }^{3}$ - Triacylglycerol (TAG)
} 


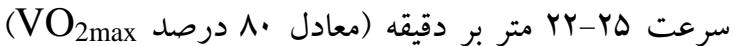

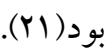

روش اندازهگيرى متغيرها: براى تهيه و تحليل نمونه خونى، بودال،

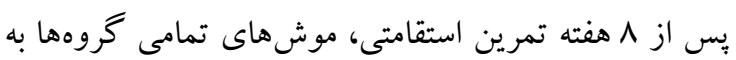

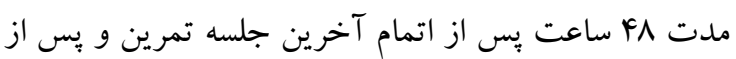
VD) VIr ساعت ناشتايى حيوان با تركيبى از داروى كتامين

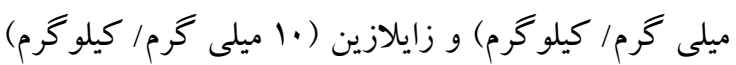
به صورت تزريق داخل صفاقى بى هوش و خون گيرى

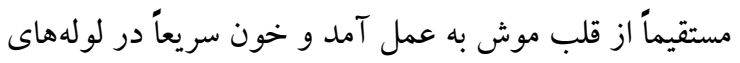

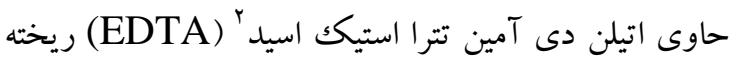
شد و براى جداكردن سرم خون، نمونهها به مدت ها دقيقه

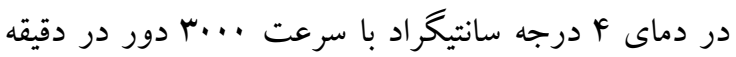

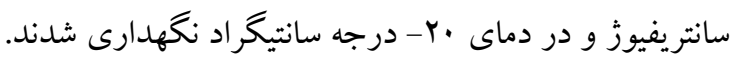
سطوح سرمى كلوكز به وسيله كلوكومتر ساخت كشور آلمان از طريق بريدن نوك دم و سطوح سرمى انسولين با كيت الايزا ويزه موش صحرايى ( Insulin rat ELISA ساخت كميانى DEV8811 با حساسيت ng/mL / • اندازهيرى شد(19). استخراج بافت: پِ از انجام يروتكل تمرينى، YF ساعت بعد از آخرين جلسه تمرين، بافت عضله نعلى تمام موشهاى

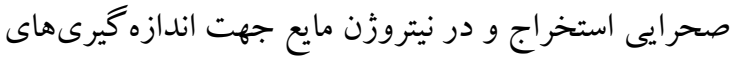

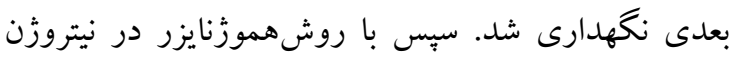

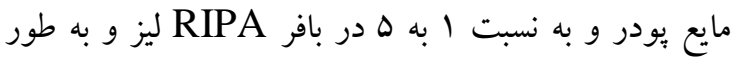
كامل هموزن و به مدت ·r دقيقه در دماى F درجه سانتى گراد قرار داده شد. سِّ به مدت بانزده دقيقه در If.. و غلظت بروتئينى محلول با روش براد فورد و با استفاده

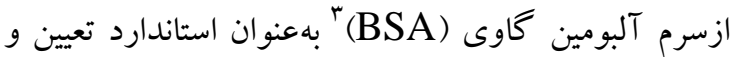

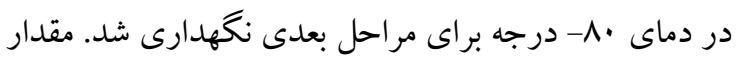
بافتى بروتئين ATGL طبق دستور العمل روش وسترنبلات

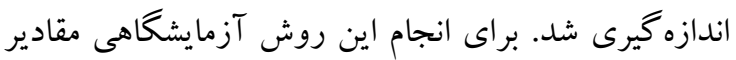

${ }^{2}$ Ethylenediaminetetraacetic acid

3 - Bovin serum albumin
حيوانات: تعداد .f موش صحرايى نر نزاد ويستار در سن

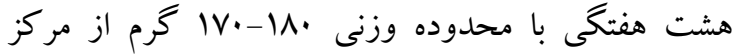

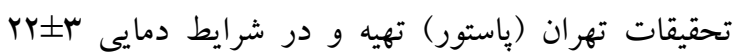

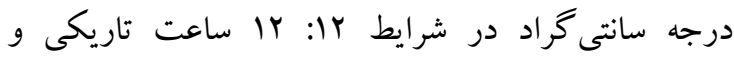
روشنايى نخهدارى و با غذاى مخصوص موش صحر درايى و وران

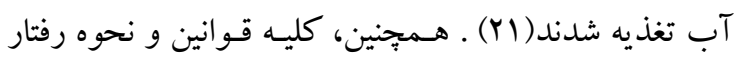

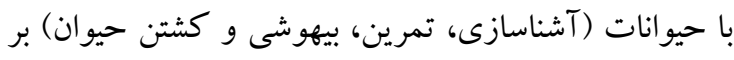
اساس ) بر اساس 'AAALAC و تائيد كميته اخلاق شوراى يزوهشى و تحصيلات تكميلى دانشكاه رعايست

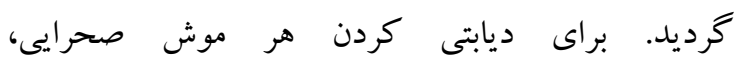

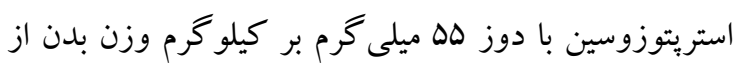
راه صفاقى تزريق شد(N) ساعت بى غذايى هر حيوان قبل از تزريق استريتوزوسين و نيز به ترتيب در فاصله زمانى ا، ب و ها روز يس از تزريق استريتوزوسين اندازه گيرى شد و موشهايى كه داراى قند

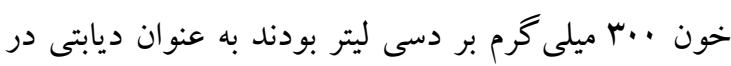

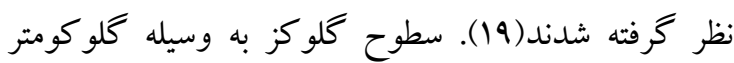
ساخت كشور آلمان، از طريق ايجاد يك جراحت كوجکك توسط لانست روى وريد دم موش ها اندازه گيرى شد. بروتكلهاى تمرين استقامتى : بعد از كذشت يك هفته و و

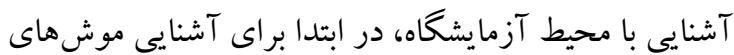
صحرايى با دويدن روى تردميل، به مدت يكك هفته با باليال سرعتى معادل ه-ץ متر بر دقيقه به مدت پانزده تا بيست دقيقه تمرين در نظر گرفته شد(·r). موشهاى صحرايى بهصورت

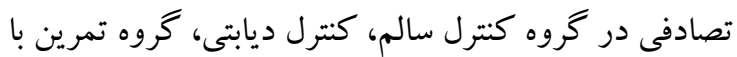
شدت متوسط و گروه تمرين با شدت بالا تقسيم شدند. شدت تمرين در گروه تمرين استقامتى كم شدت معادل

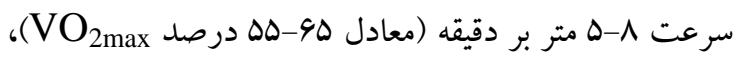

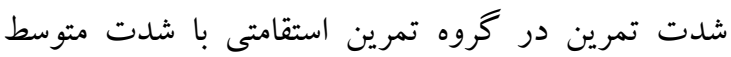

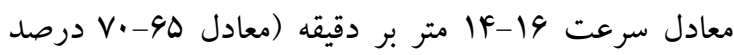
و در گروه تمرين استقامتى با شدت بالا معادل

1 Association for Assessment and Accreditation of Laboratory Animal Care International

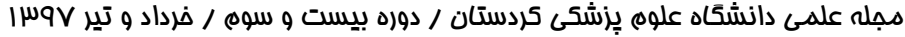


يافته ها

نتايج آزمون تحليل واريانس يكك طرفه نشان دهنده تأثير

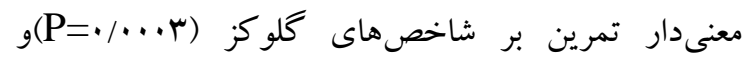

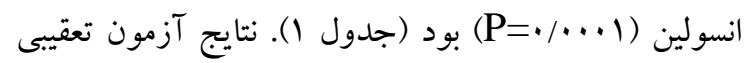

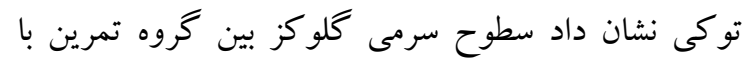

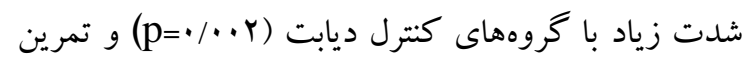

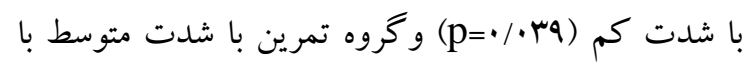

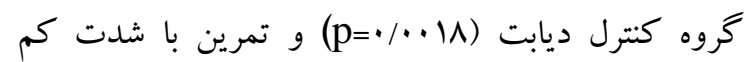
(p=•/190) تفاوت معنى دارى داشت. همجنين ، مقدار

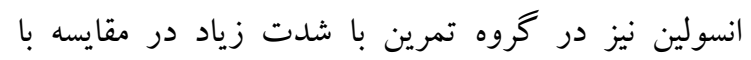

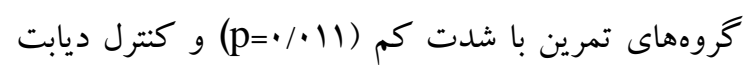
و نيز گروه تمرين با شدت متوسط با كنترل

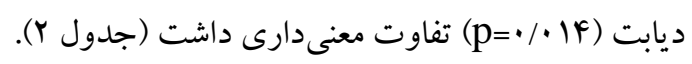

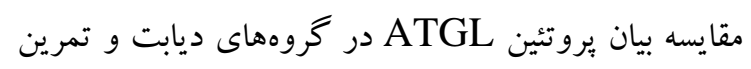

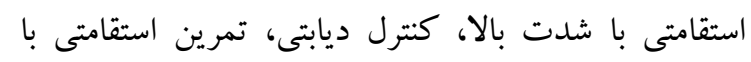

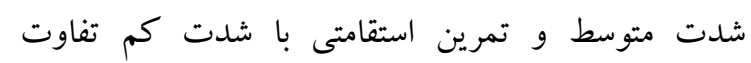

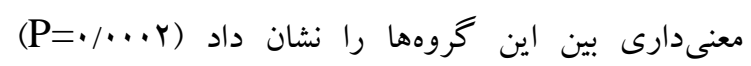
(جدول (). نتايج آزمون تعقيبى توكى نشان داد اين تفاوت

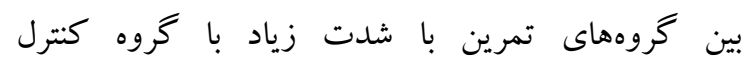

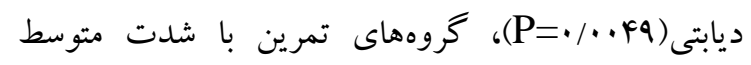

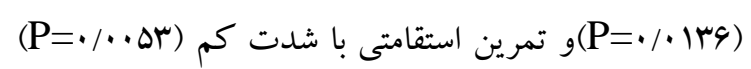

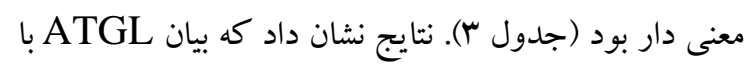

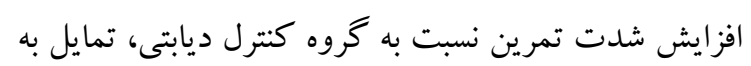

$$
\text { افزايش داشت (نمودار ()). }
$$

SDS- مساوى از يروتئين به وسيله زل يلى آكربل آميد PAGE الكتروفورز، بروتئين هاى زل به كاغذ PVDF منتقل شده و كاغذ به مدت يكك ساعت و نيم در محلول بلاكينك جهت يوشاندن جايغاههاى اتصال غير اختصاصى يروتئين قرار كرفت. سيس كاغذ يك شب در آنتىبادى اوليه ( rabbit (polyclonal to ATGL antibody- ab99532 شركت abcam در \& درجه سانتى گراد قرار داده شد و در

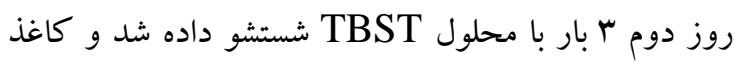

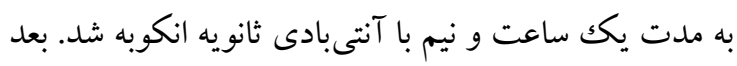

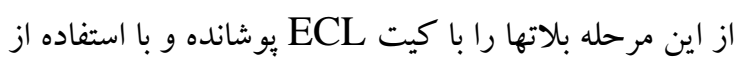
دستخاه اسكنر LI-COR ساخت امريكا باند يروتئينها مشخص شدند(Y). روش آمارى: پِس از جمع آورى دادهها، ابتدا جهت تعبين

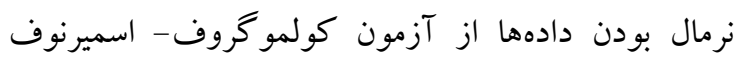

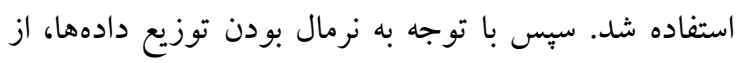

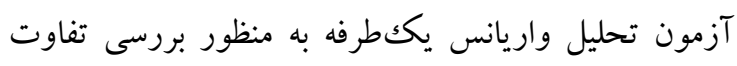

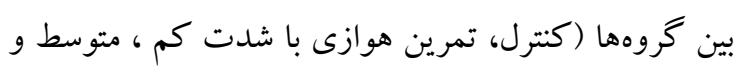

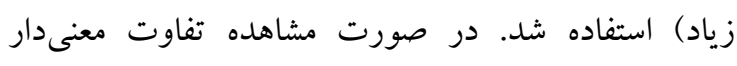

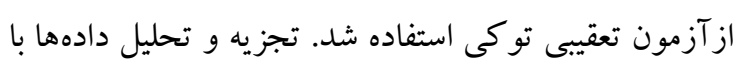

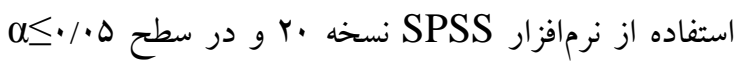
انجام گرفت. 


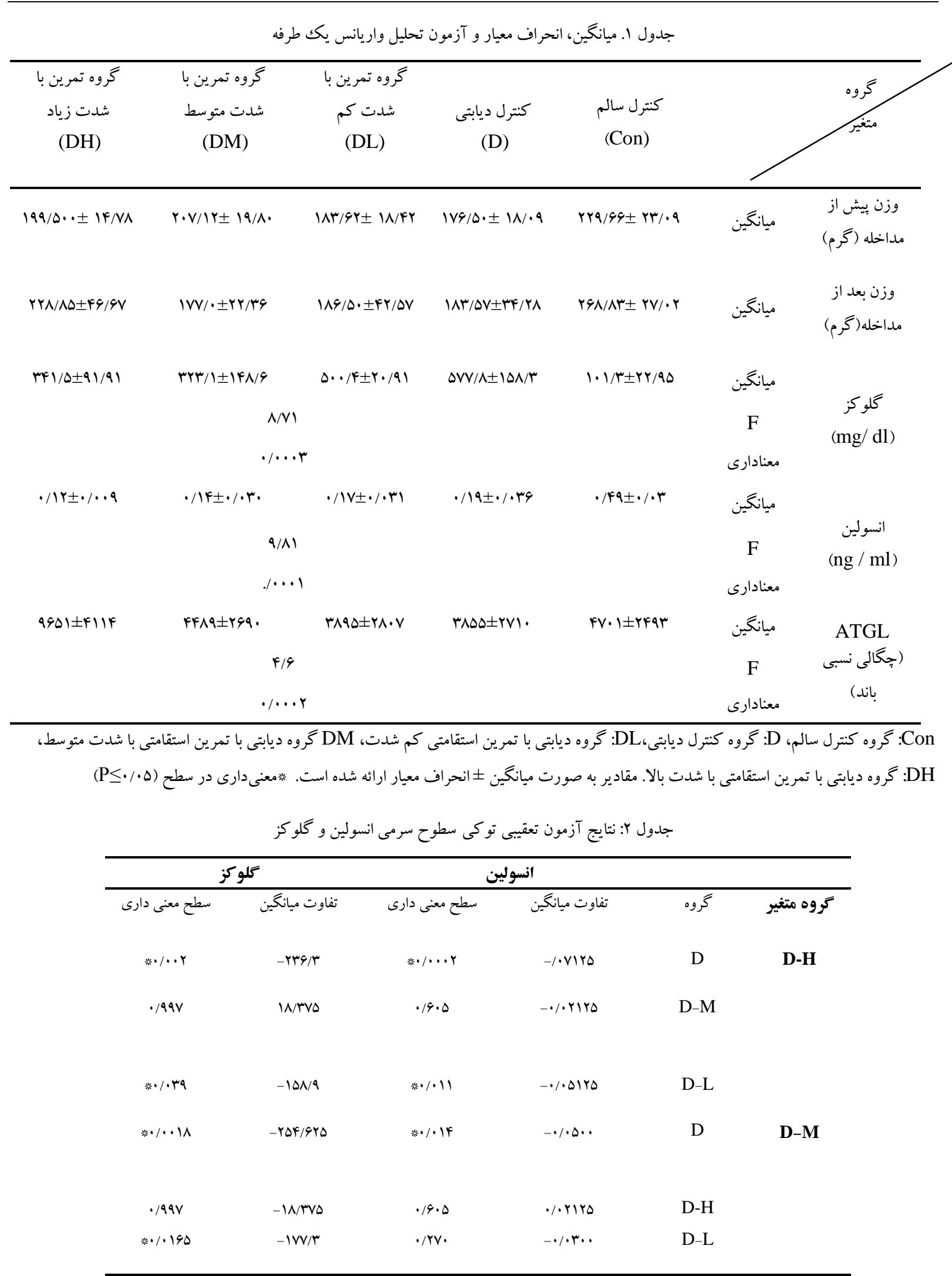




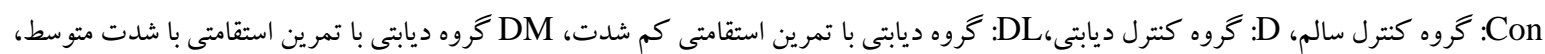
DH

جدول ب نتايج آزمون تعقيب تو كى بر ميزان بيان ATGL

\begin{tabular}{|c|c|c|c|}
\hline معنى دارى & تفاوت ميانغين & كروه & كروه متغير \\
\hline.$/ \cdots k q^{* *}$ & $\Delta \vee Q Q$ & $\bar{D}$ & D-H \\
\hline$\cdot / \cdot 1 \mu q_{*}$ & DIAT & D-M & \\
\hline$\cdot / \cdot \Delta r^{*}$ & $\Delta V \Delta V$ & D-L & \\
\hline
\end{tabular}

Con

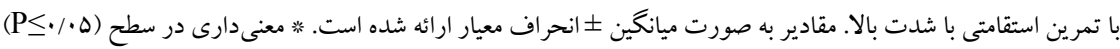

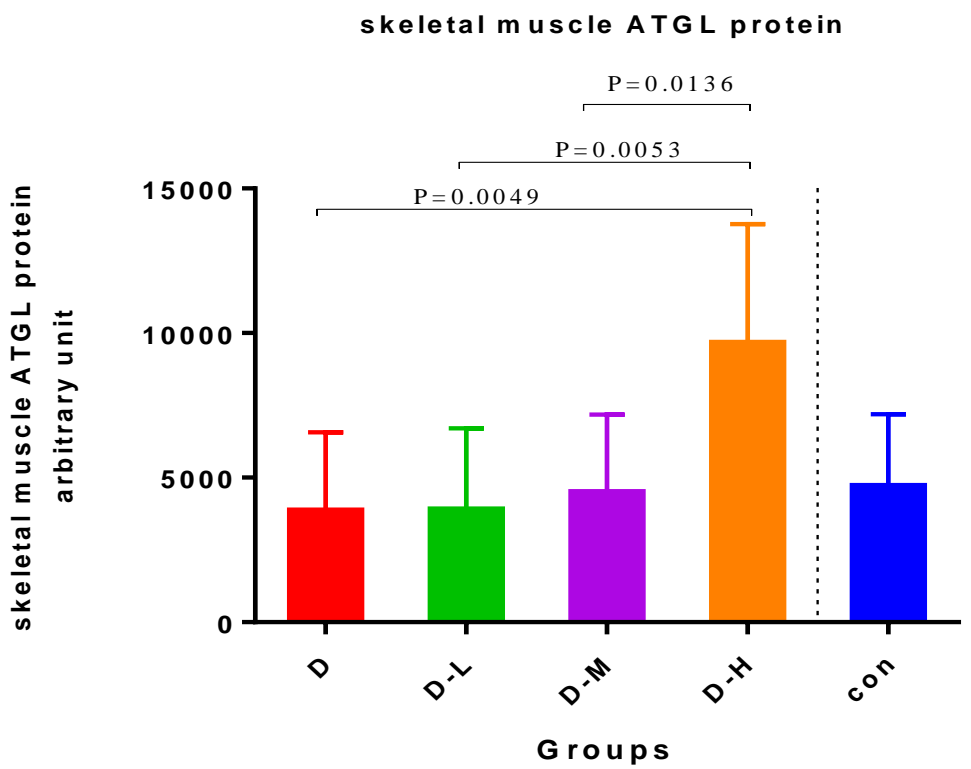

نمودار ا : مقايسه شدت تمرينات استقامتى بر بيان يروتئين ATGL در گروههاى تمرينى.D: كروه كنترل ديابتى،DL: گروه ديابتى با تمرين استقامتى كم شدت، DM گروه ديابتى با تمرين استقامتى با شدت متوسط، DH: كروه ديابتى با تمرين استقامتى با شدت بالا Con: كروه كنترل سالم 


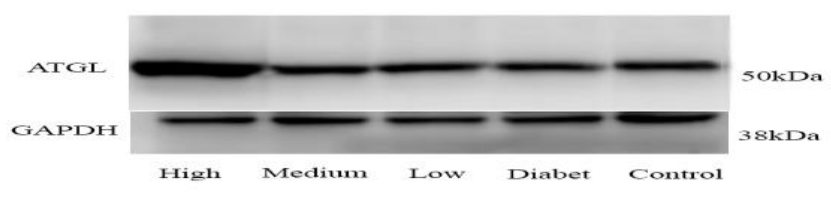

شكل ا: خگالى باند يروتئين ATGL در گروهها

بالا و مدت طولانى، احتمالاً از طريق افزايش انتقال كلوكز

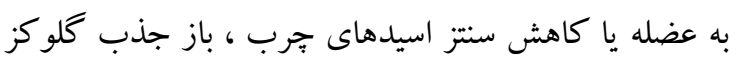

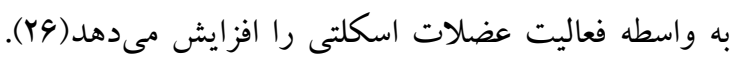

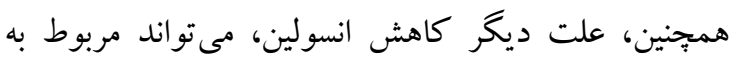

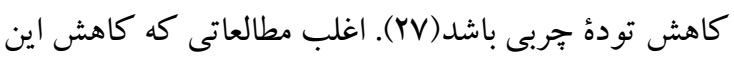

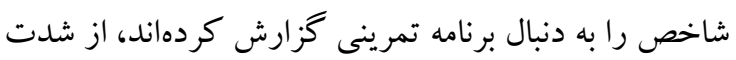

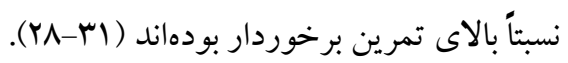

در افراد سالم، عضلات مسئول جذب بيش از •^ درصد

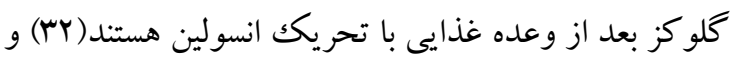
در تمرين استقامتى ، تحريك جذب كلوكز مستقل از انسولين بوده و به جاى آن از طريق مسيرهاى ناشى از

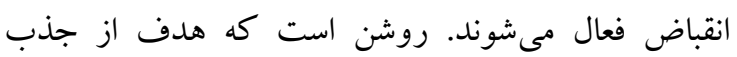
كلوكز بدون حضور انسولين هنگام تمرين مىتواند براى

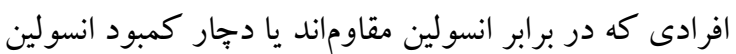

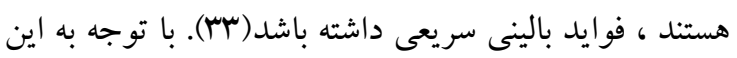

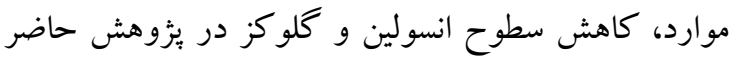
منطقى به نظر مىرسد.

همجنين، بيان بروتئين ATGL در بين گروههاى ديابت و تمرين با شدت زياد در مقايسه با ديابت و تمرين با شدت

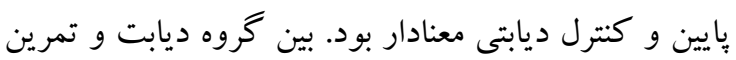
با شدت زياد در مقايسه با ديابت و تمرين با شدت متوسط هم معنادار بود (P</•). به نظر مىرسد افزايش معنى دار ATGL بسيج و مصرف IMTGs از طريق متابوليت هاى درون

\section{بحث}

در مقاومت به انسولين، محتوى جِربى عضله اسكلتى عامل قوىترى در مقايسه با اسيدهاى جرب آزاد در افراد كم تحرك مىباشد(س). حفظ هموستاز مناسب IMTG از طريق تمرينات ورزشى جهت جلو گيرى از ييدايش بيمارىهاى متابوليكى از جمله مقاومت به انسولين و ديابت نوع دو بسيار حياتى است و بى نظمى در ديناميك قطرات جربى(LDs)' و يا بيان يروتئينى LD ها در حساسيت به انسولين و ليِوتاكسيتى اثر كذار مىباشد(YF). يافتها نشان داد سطوح انسولين و كلوكز همراه با افزايش شدت تمرين استقامتى در موشهاى ديابتى كاهش يافت. كاهش سطوح سرمى انسولين و گلو كز در گرووهاى ديابت و تمرين با شدت زياد و ديابت و تمرين با شدت متوسط در مقايسه با كنترل ديابتى و ديابت و تمرين با شدت بايين

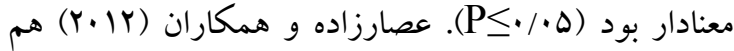
در مطالعات خود نشان دادند تمرينات تركيبى در مردان غيرفعال موجب كاهش معنادار غلظت انسولين و شاخص مقاومت به انسولين شد(YD). سازو كارهاى احتمالى كاهش انسولين و كلوكز سرمى در اثر تمرينات استقامتى مىتواند

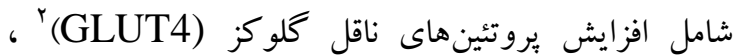
كاهش ترشح و افزايش پياكك سازى اسيدهاى جرب آزاد، افزايش تحويل كلوكز به عضلات و تغيير در افزايش تمايل عضلات به كلوكز در دسترس باشد. تمرين ورزشى با شدت

${ }^{1}$ Lipid Droplets

2 - Glucose transporter 4 (GLUT-4) 
FA تمرين و ميزان دسترسى به سوبسترا، ميزان استفاده از براى متابوليسم اكسيداسيون در زمان تمرينات استقامتى متو سط به بالاترين حد مىرسد (F). (F). عضلات اسكلتى هنكام استراحت و فعاليت ورزشى به مقدار

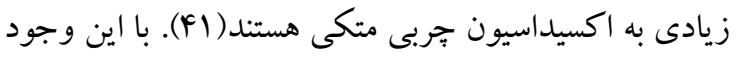
در شدتهاى بالاتر، عليرغم افزايش لييوليز بافت جربى،

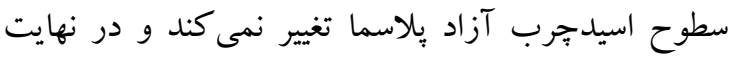
افزايش بيان ATGL در موش هاى ديابتى، باعث افزايش لييوليز و در نتيجه رهايش اسيدهاى جرب بيشتر مى شود و در

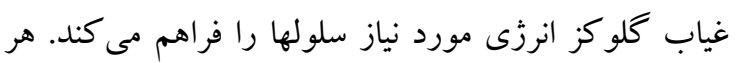
جند عوامل ثابت شده ديخرى مانند كاهش انسولين و ورون مسيرهاى آلفا آدرنرزيك نيز براى افزايش لييوليز در افراد

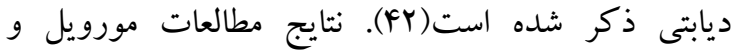
همكاران (Y.IV) هم نشان داد تكرار تمرين طولانى مدت اكسيداسيون جربى در مردان مسن را كاهش و باعث افزايش قابل توجهى در بيان يروتئين HLUT4 GII و ATGL شد كه نشان دهنده افزايش ظرفيت انتقال كلو كز و ئر افزايش ظرفيت لييوليز عضله و در نهايت كمكك به افزايش سهم گلوكز خارجى و جربى درون سلولى هنگام تمرين

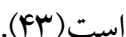

از طرفى ديخر بر خلاف نتايج تحقيق حاضر، لوج و

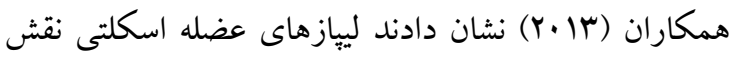
مهمى در اختلالات متابوليكك مرتبط با جاقى بازى مى كنند

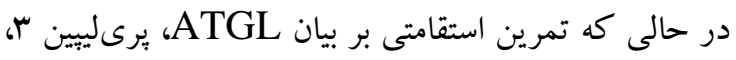

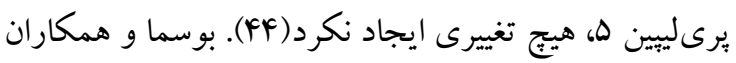
(Y.|F) هم، در تحقيقات خود بيشنهاد كردند مطالعات بيشترى براى تعيين ميزان شدت فعاليت ورزشى برمتابوليسم

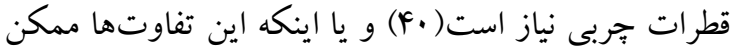

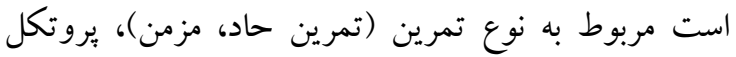

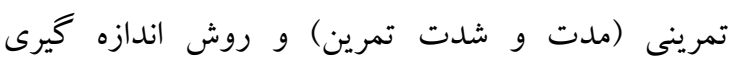
ATGL
سلولى و هورمونى تنظيم گردد. سجاديان و همكاران

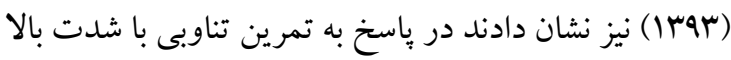
سطوح آنزيم ATGL افزايش مىيابد(F). برخلاف لييوليز بافت جربى كه به مرور زمان بر اثر تخليه انرزى بداند

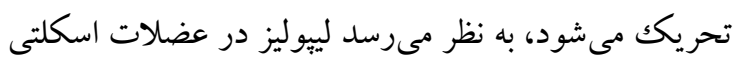

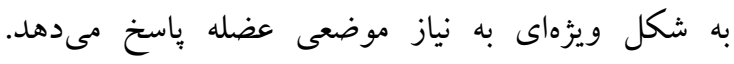

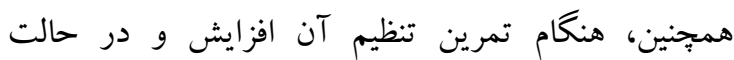

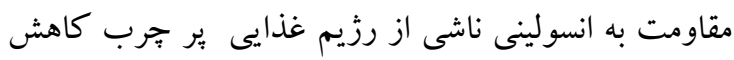

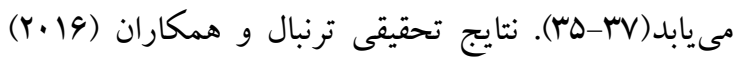

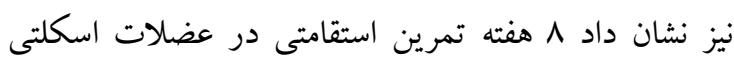
موش صحرايى باعث افزايش يروتئين ATGL در تمام

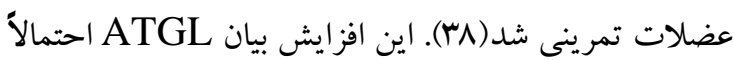
باعث حفظ غلظت كم متابوليت هاى اسيد جرب عضلانى و در نهايت به بهبود حساسيت به انسولين در تمرينهاى شديد

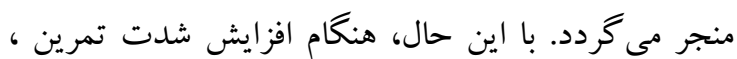

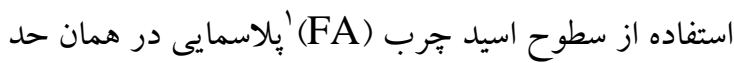
باقى مانده، اما لييوليز IMTG s در شدتهاى بالاتر

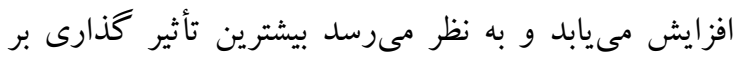
آنها در اين دامنه باشد(YV). در همين راستا شفرد و همكاران با مقايسه دو شيوه تمرين استقامتى و تمرين تناوبى

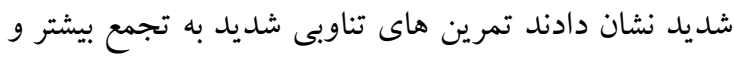
تجزيه بيشتر IMTG نسبت به تمرينهاى استقامتى منجر مى گردد ـ هنغام تمرين تناوبى با شدت بالا منابع مورد استفاده براى اكسيداسيون خربى از اسيدهاى خرب خِّاسما بيشتر به سمت IMTG سوق داده مىشود(N)). آنها دريافند افزايش ميزان تجزية IMTG با افزايش حساسيت به انسولين متعاقب تمرين ورزشى ارتباط دارد. در واقع،

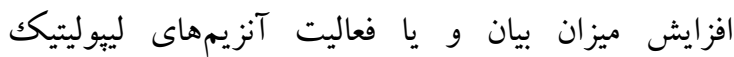
توسط تمرينات استقامتى، تجزيه

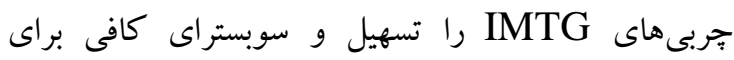

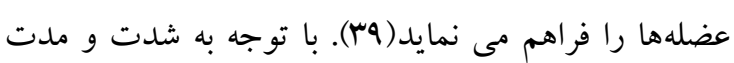

1- fatty $\operatorname{acid}(\mathrm{FA})$ 


$$
\begin{aligned}
& \text { تشكر و قدردانى } \\
& \text { بدينوسيله از تمامى كسانى كه ما را در انس انجام اين تحقيق } \\
& \text { يارى نمودهاند تقدير و تشكر مىنمايم. اين مقاله برگرفته از }
\end{aligned}
$$

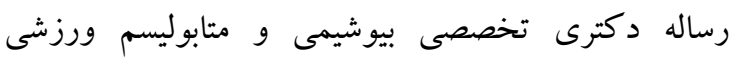

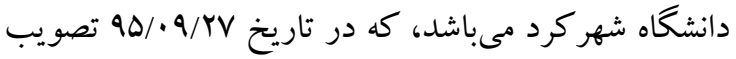

$$
\begin{aligned}
& \text { شده است. }
\end{aligned}
$$

\section{Reference}

1. Schenk S, Horowitz JF. Acute exercise increases triglyceride synthesis in skeletal muscle and prevents fatty acid-induced insulin resistance. J Clin Invest 2007;117:1690.

2. Shepherd SO, Cocks M, Tipton K, Ranasinghe AM, Barker TA, Burniston JG, et al. Sprint interval and traditional endurance training increase net intramuscular triglyceride breakdown and expression of perilipin 2 and 5. J Physiol 2013; 591: 657-75.

3. Fröberg SO, Mossfeldt F. Effect of prolonged strenuous exercise on the concentration of triglycerides, phospholipids and glycogen in muscle of man. Acta Physiologica 1971;82:16771.

4. MacPherson RE, Ramos SV, Vandenboom R, Roy BD, Peters SJ. Skeletal muscle PLIN proteins, ATGL and CGI-58, interactions at rest and following stimulated contraction. Am J Physiol Regul Integr Comp 2013;304: R644-R50.

5. Prats C, Donsmark M, Qvortrup K, Londos C, Sztalryd C, Holm C, et al. Decrease in intramuscular lipid droplets and translocation of HSL in response to muscle contraction and epinephrine. J Lipid Res 2006; 47: 2392-9.

6. Zimmermann R, Strauss JG, Haemmerle G, Schoiswohl G, Birner-Gruenberger R, Riederer $\mathrm{M}$, et al. Fat mobilization in adipose tissue is promoted by adipose triglyceride lipase. Science 2004; 306: 1383-6.

7. Fanelli C, Calderone S, Epifano L, De Vincenzo A, Modarelli F, Pampanelli S, et al. Demonstration of a critical role for free fatty acids in mediating counterregulatory stimulation of gluconeogenesis and suppression of glucose utilization in humans. J Clin Invest 1993; 92: 1617.

8. Villena JA, Roy S, Sarkadi-Nagy E, Kim K-H, Sul HS. Desnutrin, an adipocyte gene encoding a novel patatin domain-containing protein, is induced by fasting and glucocorticoids ectopic expression of desnutrin increases triglyceride hydrolysis. J Biol Chem 2004; 279: 47066-75.

9. Wei Wu J, Wang SP, Casavant S, Moreau A, Yang GS, Mitchell GA. Fasting energy homeostasis in mice with adipose deficiency of desnutrin/adipose triglyceride lipase. Endocrinology 2012; 153: 2198-207.

10. Sitnick MT, Basantani MK, Cai L, Schoiswohl G, Yazbeck CF, Distefano G, et al. Skeletal muscle triacylglycerol hydrolysis does not influence metabolic complications of obesity. Diabetes 2013; 62: 3350-61.

11. Fischer J, Lefèvre C, Morava E, Mussini J-M, Laforêt P, Negre-Salvayre A, et al. The gene encoding adipose triglyceride lipase (PNPLA2) is mutated in neutral lipid storage disease with myopathy. Nat Genet 2007; 39: 28-30. 
12. Schweiger M, Lass A, Zimmermann R, Eichmann TO, Zechner R. Neutral lipid storage disease: genetic disorders caused by mutations in adipose triglyceride lipase/PNPLA2 or CGI58/ABHD5. Am J Physiol Endocrinol Metab 2009; 297: E289-E96.

13. Haemmerle G, Lass A, Zimmermann R, Gorkiewicz G, Meyer C, Rozman J, et al. Defective lipolysis and altered energy metabolism in mice lacking adipose triglyceride lipase. Science 2006; 312: 734-7.

14. Alsted TJ, Nybo L, Schweiger M, Fledelius C, Jacobsen P, Zimmermann R, et al. Adipose triglyceride lipase in human skeletal muscle is upregulated by exercise training. Am J Physiol Endocrinol Metab 2009; 296: E445-E53.

15. Achten J, Gleeson M, Jeukendrup AE. Determination of the exercise intensity that elicits maximal fat oxidation. Med Sci Sports Exerc 2002; 34: 92-7.

16. Valizadeh A, Khosravi A, Azmoon H. Fat oxidation rate during and after three exercise intensities in non-athlete young men. WASJ 2011; 15: 1260-6. [In Persian]

17. Hashimoto T, Sato K, Iemitsu M. Exercise-inducible factors to activate lipolysis in adipocytes. J Appl Physiol 2013; 115: 260-7.

18. Szkudelski T. The mechanism of alloxan and streptozotocin action in B cells of the rat pancreas. Physiol Res 2001; 50: 537-46.

19. Pushparaj P, Low H, Manikandan J, Tan B, Tan C. Anti-diabetic effects of Cichorium intybus in streptozotocin-induced diabetic rats. J Ethnopharmacol 2007; 111: 430-4.

20. Wisløff U, Helgerud J, Kemi OJ, Ellingsen Ø. Intensity-controlled treadmill running in rats: V o 2 max and cardiac hypertrophy. Am J Physiol Heart Circ Physiol 2001; 280: H1301H10.

21. Kim D-H, Kim S-H, Kim W-H, Moon C-R. The effects of treadmill exercise on expression of UCP-2 of brown adipose tissue and TNF- $\alpha$ of soleus muscle in obese Zucker rats. J Exerc Nutrition Biochem 2013; 17: 199-207.

22. Ghafari M, Banitalebi E, Faramarzi M, Mohebi A. Comparison of Two Intensities of Aerobic Training (low intensity and High Intensity) on Expression of Perlipin 2 Skeletal Muscle, Serum Glucose and Insulin levels in Streptozotocin-Diabetic Rats. Armaghane danesh 2017; 22: 282-94. [In Persian]

23. Laurens C, Moro C. Intramyocellular fat storage in metabolic diseases. HMBCI 2016; 26: 43-52.

24. Badin P-M, Langin D, Moro C. Dynamics of skeletal muscle lipid pools. Trends Endocrinol Metab 2013; 24: 607-15.

25. Assarzade Noushabadi Mohsen, Abedi B. The combined effects of exercise on insulin resistance and some inflammatory markers in men inactive. Horizon Med Sci 2012; 18: 96101. [In Persian]

26. Kim ES, Im JA, Kim KC, Park JH, Suh SH, Kang ES, et al. Improved insulin sensitivity and adiponectin level after exercise training in obese Korean youth. Obesity 2007; 15: 302330 .

27. Pasman W, Westerterp-Plantenga M, Saris W. The effect of exercise training on leptin levels in obese males. Am J Physiol Endocrinol Metab 1998; 274: E280-E6.

28. Kelley DE, Goodpaster BH. Effects of physical activity on insulin action and glucose tolerance in obesity. Med Sci Sports Exerc 1999; 31: S619-23.

29. Ivy JL. Role of exercise training in the prevention and treatment of insulin resistance and non-insulin-dependent diabetes mellitus. Sports Med 1997; 24: 321-36. 
30. James D, Burleigh K, Kraegen EW, Chisholm D. Effect of acute exercise and prolonged training on insulin response to intravenous glucose in vivo in rat. J Appl Physiol 1983; 55: $1660-4$.

31. Berger M, Kemmer F, Becker K, Herberg L, Schwenen M, Gjinavci A, et al. Effect of physical training on glucose tolerance and on glucose metabolism of skeletal muscle in anaesthetized normal rats. Diabetologia 1979; 16: 179-84.

32. DeFronzo RA, Tripathy D. Skeletal muscle insulin resistance is the primary defect in type 2 diabetes. Diabetes Care 2009; 32: S157-S63.

33. Stephenson EJ1, Smiles W, Hawley JA.The relationship between exercise, nutrition and type 2 diabetes. Med Sport Sci 2014; 60: 1-10.

34. Sajadian S, Nikooie R. TGF- $\beta 1$ protein expression in the skeletal muscle following high interval training and its relationship with intramuscular triglycerides oxidation. Journal of Sport in Biomotor Sciences 2015; 6: 45-54. [In Persian]

35. Holloszy JO, Coyle EF. Adaptations of skeletal muscle to endurance exercise and their metabolic consequences. Eur J Appl Physiol 1984; 56: 831-8.

36. Kim C-H, Kim M-S, Youn J-Y, Park H-S, Song H-S, Song KH, et al. Lipolysis in skeletal muscle is decreased in high-fat-fed rats. Metabolism 2003; 52: 1586-92.

37. Romijn J, Coyle E, Sidossis L, Gastaldelli A, Horowitz J, Endert E, et al. Regulation of endogenous fat and carbohydrate metabolism in relation to exercise intensity and duration. Am J Physiol Endocrinol Metab 1993; 265: E380-E91.

38. Turnbull PC, Longo AB, Ramos SV, Roy BD, Ward WE, Peters SJ. Increases in skeletal muscle ATGL and its inhibitor G0S2 following 8 weeks of endurance training in metabolically different rat skeletal muscles. Am J Physiol Regul Integr Comp Physiol 2016; 31: R125-R33.

39. Yao-Borengasser A, Varma V, Coker RH, Ranganathan G, Phanavanh B, Rasouli N, et al. Adipose triglyceride lipase expression in human adipose tissue and muscle. Role in insulin resistance and response to training and pioglitazone. Metabolism 2011; 60: 1012-20.

40. Bosma M. Lipid homeostasis in exercise. Drug discov Today 2014;19:1019-23.

41. Holloway GP, Bezaire V, Heigenhauser GJ, Tandon NN, Glatz JF, Luiken JJ, et al. Mitochondrial long chain fatty acid oxidation, fatty acid translocase/CD36 content and carnitine palmitoyltransferase I activity in human skeletal muscle during aerobic exercise. $\mathbf{J}$ Physiol 2006; 571: 201-10.

42. Howe HR, Heidal K, Choi MD, Kraus RM, Boyle K, Hickner RC. Increased adipose tissue lipolysis after a 2-week high-fat diet in sedentary overweight/obese men. Metabolism 2011; 60: 976-81.

43. Morville T, Rosenkilde M, Munch-Andersen T, Andersen PR, Kjær GK, Helbo S, et al. Repeated prolonged exercise decreases maximal fat oxidation in older men. Med Sci Sports Exerc 2017; 49: 308-16.

44. Louche K, Badin P-M, Montastier E, Laurens C, Bourlier V, De Glisezinski I, et al. Endurance exercise training up-regulates lipolytic proteins and reduces triglyceride content in skeletal muscle of obese subjects. J Clin Endocrinol Metab 2013; 98: 4863-71. 